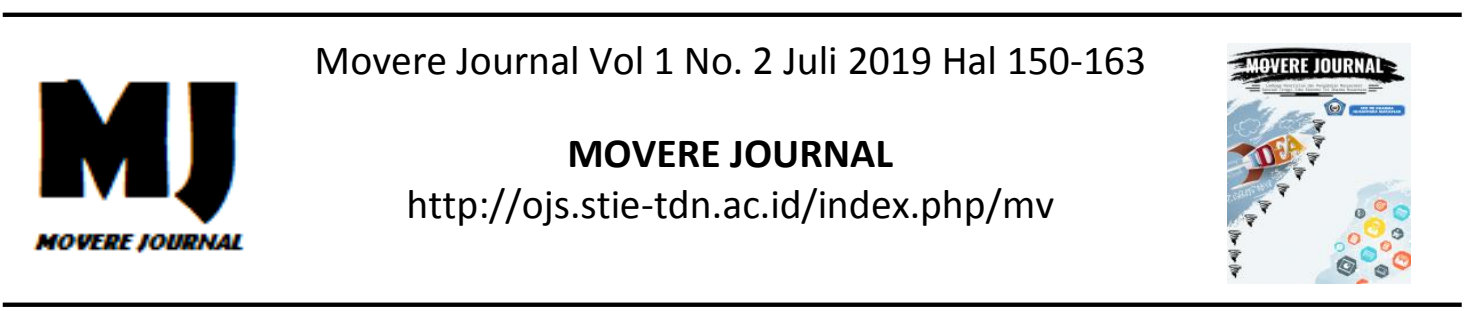

\title{
GAYA KEPEMIMPINAN DAN BUDAYA ORGANISASI: PENGARUHNYA TERHADAP KINERJA KARYAWAN
}

\author{
Asmawiyah \\ STIE Tri Dharma Nusantara
}

\begin{abstract}
Abstrak : Penelitian ini bertujuan untuk mengetahu pengaruh gaya kepemimpinan dan budaya organisasi terhadap kinerja karyawan PT. Japfa Comfeed Indonesia, Tbk Unit Makassar. Model Penelitian yang digunakan dalam penelitian ini yakni dengan metode observasi, wawancara, kuesioner, dan studi kepustakaan yang dilakukan secara sistematik berdasarkan tujuan penelitian. Sampel pada penelitian ini adalah 95 responden. Metode analisis yang digunakan yaitu analisis regresi linear berganda, analisis koefisien determinasi (R2), uji T (parsial) dan uji F (serempak). Dari hasil penelitian menunjukkan bahwa gaya kepemimpinan mempunyai pengaruh yang positif dan signifikan terhadap kinerja karyawan sedangkan budaya organisasi mempunyai pengaruh positif namun tidak signifikan terhadap kinerja karyawan. Hal ini menjadikan gaya kepemimpinan merupakan variabel yang paling dominan mempengaruhi terhadap kinerja karyawan pada PT. Japfa Comfeed Indonesia, Tbk Unit Makassar.
\end{abstract}

Kata kunci : Gaya kepemimpinan, Budaya Organisasi, Kinerja Karyawan

\section{PENDAHULUAN}

Di era globalisasi, persaingan perusahaan semakin tinggi dan semakin kompleks sehingga setiap perusahaan di tuntut untuk memperbaiki hal-hal yang terkait dalam setiap perusahaan dan lebih responsive agar terus bertahan dan terus berkembang. Hal-hal yang mesti di perbaiki adalah semua aspek khusunya pada sumber daya manusia. Oleh karena itu sumber daya manusia merupakan salah satu faktor yang sangat penting bahkan tidak bisa dilepaskan dari sebuah organisasi, baik perusahaan ataupun instuisi.Selain itu SDM juga merupakan faktor yang mempengaruhi perkembangan suatu perusahaan. Manajemen sumber daya manusia untuk seperti di organisasi publik atau organisasi pemerintahan berusaha menciptakan manusia sebagai sumber daya seutuhnya dalam konsepsi pembangunan suatu perusahaan yang utuh dan menyeluruh. Berbagai permasalahan yang dihadapi oleh organisasi. Sumber daya manusia (SDM) merupakan aspek penting dalam melakukan kegiatan organisasi dalam suatu perusahaan. Sumber daya manusia yang berkaitan dengan ketersediaan tenaga terampil seringkali menjadi kendala masalah yang sangat mendasar. Namun penyediaan tenaga terampil dapat diupayakan melalui pelatihan-pelatihan biasanya memanfaatkan warga sekitar lokasi budidaya kerang mutiara yang tidak mempunyai pekerjaan tetap,sehingga dapat menciptakan lapangan kerja baru bagi mereka.

Upaya-upaya dalam meningkatkan kinerja karyawan selain pengendalian internal gaya kepemimpinan juga perlu 
di perhatikan. Seorang pemimpin yang ideal harus memiliki gaya kepemimpinan yang baik sehingga dapat meningkatkan kinerja karyawan Seorang pemimpin sangat perlu memperhatikan gaya kepemimpinan dalam proses mempengaruhi, mengarahkan kegiatan anggota kelompoknya serta mengkordinasikan tujuan anggota dan tujuan organisasi agar keduanya dapat tercapai Gaya kepemimpinan yang baik adalah gaya kepemimpinan yang dapat memberikan motivasi kerja pada bawahannya.

Kepemimpinan dianggap sebagai salah satu fungsi utama manajemen dalam mencapai tujuan dan produktivitas organisasi. Dalam mencapai tujuan organisasi tidak mungkin atau sangat sulit tanpa kepemimpinan. Manajemen atau gaya kepemimpinan ditentukan oleh keberadaan budaya dan strategi dalam organisasi (Yuan dan Lee, 2011). Kepemimpinan memainkan peran penting dalam menciptakan suasana dan budaya yang antusias dalam suatu organisasi (Alghazo \& Al-Anazi, 2016). Hurduzue (2015) menyatakan bahwa gaya kepemimpinan yang efektif dapat mempromosikan keunggulan dalam pengembangan anggota organisasi. Unsur-unsur utama untuk menentukan keberhasilan kelompok adalah kepemimpinan (Robbins, 2003). Kepemimpinan selalu dikaitkan dengan kemampuan untuk memengaruhi perilaku karyawan dalam kelompok menuju pencapaian sasaran. Kepemimpinan selalu tentang sesuatu untuk menangani perubahan.

Peran pemimpin mempengaruhi perilaku bawahan untuk mendapatkan peran dalam kemajuan organisasi (Bass, 1990). Hal ini didukung oleh Fiedler dalam Robbins (2003) bahwa kinerja kelompok yang efektif tergantung pada gaya kepemimpinan seorang pemimpin dalam organisasi
Gaya kepemimpinan akan sangat berpengaruh pada kondisi kerja, motivasi dan keyakinan karyawan dan mengarah pada peningkatan kinerja. Kebalikannya dapat menyebabkan penurunan kinerja jika aplikasi tidak disesuaikan dengan kondisi perilaku kerja anggota organisasi (Gibson et al, 2000). Kinerja rendah dalam perspektif kepemimpinan menarik untuk dipelajari. Ini adalah tentang seberapa jauh kepemimpinan perilaku mampu menggambarkan gaya kepemimpinan dan kemampuan manajerial seorang pemimpin. Kinerja karyawan individu akan tercapai jika karyawan memiliki kedewasaan kerja. Kematangan pekerjaan ini akan tercapai ketika ada kemauan mereka dan mendapatkan referensi dari pemimpin mereka melalui model kepemimpinan.

Hubungan antara kepemimpinan dan kinerja perusahaan adalah topik penting bagi akademisi dan praktisi. Kepemimpinan dan pengaruhnya pada perusahaan dan karyawan adalah topik yang menarik. Studi kepemimpinan dimulai dengan pendekatan sifat dan diperluas dari hari ke hari. Dengan berbagai aspek, banyak gaya kepemimpinan seperti transaksional, suportif, partisipatif, super, pelayan, kewirausahaan, kepemimpinan spiritual telah muncul. Sejumlah peneliti berteori bahwa kepemimpinan terkait dengan kinerja organisasi (Howell dan Avolio, 1993; Huang, 2010). Masing-masing gaya kepemimpinan ini telah menerima perhatian penting dalam literatur manajemen dan dalam dunia bisnis.

Selain kepemimpinan, budaya organisasi juga memiliki hubungan positif yang signifikan terhadap kinerja karyawan. Budaya menjelaskan kepada karyawan apa aturan, norma dan nilai dalam organisasi. Satu variabel pada tingkat organisasi yang dapat menentukan keberhasilan organisasi 
dalam mencapai tujuannya adalah budaya organisasi (Robbins, 2003). Budaya organisasi merupakan produk interaksi antara nilai proses seleksi, fungsi perilaku manajerial dan organisasi (Gibson et al. 2000). Namun hubungan antara kepemimpinan dan kinerja dan antara budaya dan kinerja telah diperiksa secara independen, beberapa penelitian telah mencari hubungan antara tiga konsep.Banyak analisis budaya organisasi hanya memberikan sedikit perhatian kepada kepemimpinan (Trice, 1991). Jadi ada kebutuhan untuk memahami bagaimana budaya dan kepemimpinan bersama-sama mempengaruhi kinerja perusahaan. Dinamika bisnis perusahaan konstruksi saat ini telah mendorong mereka untuk lebih bergantung pada konsep budaya organisasi (Low and Shi, 2001).

Tingkat budaya organisasi dikaitkan dengan sejauh mana organisasi menunjukkan dalam empat sifat, yaitu kemampuan beradaptasi, misi, konsistensi dan keterlibatan, dan apakah mereka jelas dan dapat dimengerti baik bagi manajer dan pengikut. Beberapa model telah berevolusi untuk mengukur efektivitas budaya organisasi (Lewin dan Minton, 1986; Smart dan John, 1996). Secara khusus, penelitian ini memfokuskan perhatiannya pada model budaya organisasi yang dikenal sebagai model Denison (Denison Consulting, 2007). Fokus utama dari modul Denison adalah gaya kepemimpinan manajer dan peran pentingnya dalam membantu mempengaruhi budaya organisasi, termasuk proses dimana ini ditransfer ke bawahan. Zehir dkk. (2011) menyatakan bahwa budaya organisasi dan kepemimpinan telah menerima perhatian penting, dalam literatur manajemen, dalam hal hubungan mereka dengan berbagai hasil organisasi; misalnya, efektivitas, keunggulan kompetitif, kinerja keuangan, atau kinerja individu. Namun, studi yang mengintegrasikan kedua faktor dengan kinerja organisasi sangat sedikit. Tingkat budaya organisasi dikaitkan dengan sejauh mana organisasi menunjukkan dalam empat sifat, yaitu kemampuan beradaptasi, misi, konsistensi dan keterlibatan, dan apakah mereka jelas dan dapat dimengerti baik bagi manajer dan pengikutnya.

\section{TELAAH LITERATUR DAN PENGEMBANGAN HIPOTESIS}

\section{Gaya Kepemimpinan}

Topik kepemimpinan telah menarik banyak orang ratusan tahun bagi para sarjana dan banyak ilmuwan yang mencoba membuat definisi kepemimpinan. Bagi manusia menjadi mitos dan legenda selalu menarik apa yang membedakan para pemimpin hebat dari pengikut (Hartog dan Koopman, 2011). Peran kepemimpinan dalam organisasi telah berubah dan keberhasilan organisasi tergantung pada gaya kepemimpinan yang dipraktekkan oleh para pemimpin. Menurut Mintzberg (2010) pemimpin sejati melibatkan orang lain dengan pertimbangan dan kesederhanaan mereka karena mereka melibatkan diri dalam apa yang sebenarnya tidak mereka lakukan untuk keuntungan individu. Mullins (2005) mendefinisikan gaya kepemimpinan sebagai "cara di mana fungsi kepemimpinan dilakukan dan cara manajer memilih untuk berperilaku terhadap karyawan".

Gaya kepemimpinan adalah bentuk konsistensi perilaku lintas situasional. Ini mengacu pada cara di mana seorang pemimpin berinteraksi dengan bawahannya. Gaya kepemimpinan adalah salah satu cara yang digunakan untuk memotivasi 
karyawan. Gaya kepemimpinan harus dipilih dan disesuaikan agar sesuai dengan organisasi, situasi, kelompok dan individu. Dengan demikian berguna untuk memiliki pemahaman menyeluruh tentang berbagai gaya karena pengetahuan itu meningkatkan alat yang tersedia untuk memimpin secara efektif.

Peran kepemimpinan telah digunakan dalam berbagai aspek bisnis seperti politik, bisnis, akademisi, dan pekerjaan sosial. Menurut (Gopal dan Chowdhury, 2014) pemimpin perusahaan atau organisasi memiliki peran penting dalam kinerja karyawan dan organisasi mereka dengan memotivasi mereka. Kepemimpinan adalah seni mentransfer orang lain dalam mencapai tujuan bersama (Robbins, 2003). Pemimpin interaktif puas dengan mempertahankan kondisi yang ada dan mengarahkan bawahan mereka sedemikian rupa untuk mencapai organisasi dan tujuan anggota dan mempromosikan karyawan. Tetapi para pemimpin interaktif dianggap sebagai motivator yang lebih rendah dan memperkuat antusiasme mereka. Kepemimpinan transaksional mengacu pada perubahan dalam nilai-nilai dan prioritas karyawan dan memotivasi mereka untuk mencapai tujuan yang lebih tinggi (kark et al. 2012).

Russell (2005) kepemimpinan adalah pengaruh interpersonal yang dilakukan oleh seseorang atau orang melalui proses komunikasi, untuk mencapai tujuan organisasi. Selanjutnya, Rue dan Byars (2009) mendefinisikan kepemimpinan sebagai kemampuan untuk mempengaruhi orang lain agar bersedia mengikuti pedoman atau mematuhi keputusan yang ada. kepemimpinan sebagai suatu proses di mana individu mempengaruhi sekelompok individu untuk mencapai tujuan bersama
(Northouse, 2012,). Ada banyak gaya kepemimpinan untuk penelitian ini menggunakan gaya kepemimpinan transformasional, transaksional, laissez-faire. Gaya kepemimpinan transformasional lebih inovatif, produktif, efektif, dan memuaskan bagi para pengikut karena kedua pihak bekerja menuju kebaikan organisasi yang didorong oleh visi dan nilai bersama dan saling percaya dan menghormati (Avolio et al., 1991). Berdasarkan dari definisi-definisi yang telah dikemukakan diatas, dengan demikian dapat disimpulkan bahwa kepemimpinan adalah kemampuan mempengaruhi orang lain agar mau bekerjasama dalam mencapai tujuan yang ditetapkan.

\section{Budaya Organisasi}

Budaya organisasi dapat dijelaskan oleh banyak peneliti dalam berbagai penelitian untuk berbagai ukuran. Menurut Nongo (2012) menegaskan bahwa budaya sangat penting untuk memahami komunitas atau kelompok mana pun. Melalui proses sosialisasi individu membawa ke dalam kelompok. Kelompok memiliki kapasitas untuk membentuk, mempengaruhi, dan menentukan pandangan anggota kelompok, sudut pandang, output, sikap dan perilaku. Menurut Nelson \& Quick, (2011), budaya organisasi melakukan empat fungsi: memberi anggota rasa identitas, meningkatkan komitmen mereka, memperkuat nilai organisasi pasir berfungsi sebagai mekanisme kontrol untuk membentuk perilaku. Penting untuk dicatat bahwa para pemimpin membentuk dan memperkuat budaya dengan apa yang mereka perhatikan, bagaimana mereka bersikap, bagaimana mereka mengalokasikan imbalan dan bagaimana mereka mempekerjakan dan memecat individu. Karakteristik budaya organisasi adalah 
nilai-nilai yang menjadi pedoman karyawan dalam perilaku kerja mereka. Karyawan dituntut untuk lebih inovatif, mengambil risiko, memperhatikan detail pekerjaan dan pencapaian hasil yang berorientasi. Manajemen dalam mengambil keputusan harus memperhatikan minat karyawan dan kerja tim. Seluruh anggota organisasi dituntut untuk berperilaku dinamis dalam mencapai pertumbuhan tanpa mengabaikan kebutuhan akan kerja stabilitas batin.

Budaya organisasi merupakan hal yang penting dalam meningkatkan pencapaian tujuan dan sasaran suatu organisasi. Dan budaya organisasi memengaruhi cara orang berperilaku dalam suatu organisasi dan juga dapat menyebabkan meningkatnya karyawan di tempat kerja untuk membantu dan menjadi lebih berkomitmen terhadap pekerjaan mereka (Nongo \& Ikyanyon, 2012). Dan peneliti untuk mengukur budaya organisasi meliputi: keterlibatan, konsistensi, kemampuan beradaptasi, dan misi serta komitmen karyawan kepada organisasi. Dalam mengukur budaya organisasi dilakukan dalam hal keterlibatan, konsistensi, adaptabilitas dan misi sebagaimana diadopsi oleh Nongo (2012). Budaya organisasi memiliki peran penting dalam menjaga stabilitas sistem sosial karena mampu membentuk sikap dan perilaku karyawan. Budaya organisasi dengan ini juga meningkatkan karyawan untuk mencapai tujuan organisasi sehingga selain menggambarkan organisasi identitas, budaya organisasi juga membatasi nilai-nilai organisasi yang dimiliki secara berbeda dari budaya organisasi lain.

Budaya organisasi mencerminkan beberapa gaya perilaku kepemimpinan laten dalam organisasi (Smirisich, 2010). Berbagai jenis budaya dalam organisasi dapat mempengaruhi gaya manajemen dan kepemimpinan yang berbeda (Tsui et al., 2010). Budaya organisasi mengacu pada sistem berbagi kesimpulan anggota organisasi pada organisasi. Budaya organisasi terdiri dari dua lapisan. Lapisan pertama (nilai dan pendapat) mengacu pada simbol yang masuk akal seperti cakupan, perilaku, upacara dan ritual. Lapisan kedua adalah fondasi budaya yang mencakup semua nilai dasar, prasyarat, opini, proses mental, dan kelompok organisasi.

\section{Kinerja Karyawan}

Salah satu kunci keberhasilan suatu perusahaan adalah bergantung pada kinerja sumber daya manusia yang secara langsung atau tidak langsung memberikan kontribusi kepada perusahaan, yang meliputi pemangku kepentingan eksternal dan tujuan internal (karyawan) yang dimiliki oleh perusahaan. Gie (1995) berpendapat bahwa kinerja adalah seberapa jauh tugas atau pekerjaan dilakukan oleh seseorang atau organisasi. Kinerja diukur berdasarkan berapa banyak orang atau organisasi yang berkontribusi. hasil kualitas dan kuantitas pekerjaan yang dilakukan oleh karyawan sesuai dengan tanggung jawab mereka. Rue dan Byars (1980) mendefinisikan kinerja sebagai tingkat pencapaian atau "tingkat pencapaian". Kinerja menunjukkan tingkat pencapaian tujuan organisasi. Melalui tingkat pencapaian kinerja dapat diukur dan diketahui.

Kinerja karyawan merupakan suatu ukuran yang dapat digunakan untuk menetapkan perbandingan hasilpelaksanaan tugas, tanggung jawab yang diberikan oleh organisasi pada periode tertentu dan relatif dapatdigunakan untuk mengukur prestasi kerja atau kinerja organisasi. (Gibson et al.,1996). Kinerja atau prestasikerja seorang karyawan pada 
dasarnya adalah hasil kerja seorang karyawan selama periode waktu tertentudibandingkan dengan berbagai kemungkinan, misalnya standar, target atau kriteria lain yang ditentukan terlebihdahulu dan telah disepakati bersama. (Soeprihanto, 2000). Kinerja atau prestasi kerja adalah hasil kerja kualitasdan kuantitas yang dicapai oleh seorang pegawai dalam melaksanakan tugasnya sesuai dengan tanggung jawabyang diberikan kepadanya. (Mangkunegara, 2000). Berdasarkan dari beberapa definisi diatas, kinerja karyawandapat disimpulkan sebagai otuput atau hasil kerja karyawan sesuai dengan tugas dan tanggung jawabnya untukmencapai tujuan organisasi.

\section{Kerangka Pemikiran}

Mengingat pentingnya sumber daya manusia maka setiap perusahaan harus memperhatikan tingkat kemampuan berkepemimpinan dan berkomunikasi yang baik dan benar kepada seluruh karyawannya sehingga tercipta iklim kekeluargaan yang baik yang pada akhirnya dapat meningkatkan kinerja karyawan. Peningkatan kepemimpinan yang efektif dan benar merupakan salah satu segi dari keefektifan kerja karyawan. Hal ini sejalan dengan ahli bahwa kepemimpinan adalah cara seorang pemimpin mempengaruhi perilaku bawahan agar mau bekerjasama dan bekerja secara produktif untuk mencapai tujuan organisasi (Hasibuan, 2002:170).

Budaya organisasional merupakan suatu sistem dari kepercayaankepercayaan dan nilainilai yang berkembang dalam organisasi dan mengarahkan perilaku anggotanya. Dalam bisnis, sistemsistem ini sering dianggap sebagai corporate culture. Tidak ada dua pribadi yang sama, tidak ada budaya organisasi yang identik. Para ahli dan konsultan mempercayai bahwa perbedaan budaya memiliki pengaruh yang besar pada kinerja organisasional dan kualitas kehidupan kerja yang dialami oleh anggota organisasi (Schemerhorn, 1994:427). Byars (1984), mengartikan kinerja sebagai hasil dari usaha seseorang yang dicapai dengan adanya kemampuan dan perbuatan dalam situasi tertentu. Jadi bisa dikatakan prestasi kerja merupakan hasil keterkaitan antara usaha, kemampuan, dan persepsi tugas. Berdasarkan uraian di atas, maka hubungan antar variabel dapat digambarkan melalui kerangka konseptual sebagai berikut:

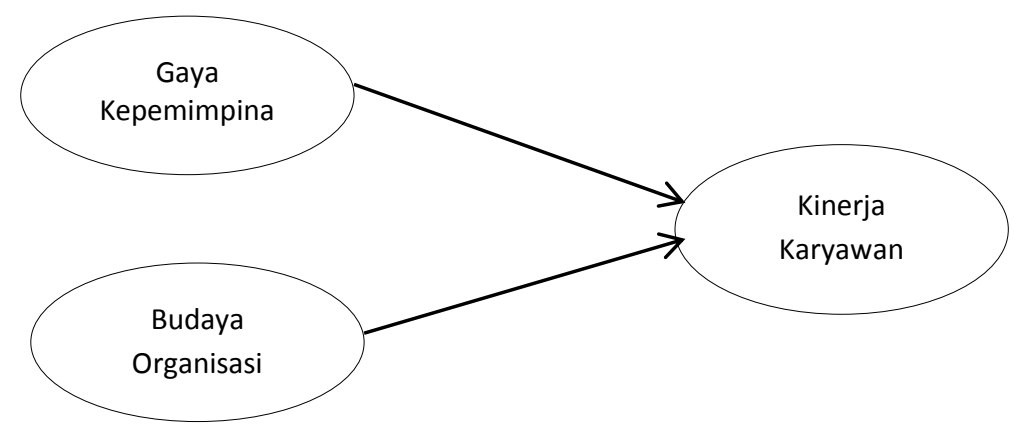

Gambar 1: Kerangka konseptual

Berdasarkan pemikiran teoritis di atas, maka hipotesis dalam penelitian ini adalah: 
H1 : Gaya kepemimpinan berpengaruh positif terhadap kinerja karyawan

$\mathrm{H} 2$ : Budaya organisasi berpengaruh positif terhadap kinerja karyawan

\section{METODE PENELITIAN}

\section{Jenis dan Sumber Data}

Adapun jenis data yang digunakan dalam penelitian ini adalah data kualitatif dan data kuantitatif. Data kualitatif adalah data yang diperoleh dari pihak perusahaan dalam bentuk uraian tugas dan penjelasan yang sifatnya non angka atau tidak berkaitan dengan angka-angka mengenai perusahaan. Data kuantitatif adalah data yang diperoleh dari perusahaan dalam bentuk daftar-daftar dokumen dan data yang dituangkan berupa angka-angka atau nominal.

\section{Populasi dan Sampel Penelitian}

Populasi dalam penelitan ini adalah jumlah dari keseluruhan karyawan dari PT. Japfa Comfeed Indonesia, Tbk Unit Makassar yang berjumlah sebanyak 95 orang. Sampel adalah bagian dari populasi yang akan diteliti dan dipandang mampu untuk mewakili. Teknik pengambilan sampel pada penelitian ini menggunakan teknik sampling jenuh, karena populasinya kecil sehingga semua populasi di jadikan sampel.

\section{Definisi Operasional}

Variabel-variabel yang digunakan dalam penelitian ini adalah sebagai berikut:

1. Gaya kepemimpinan (X1) yang menempatkan manusia sebagai faktor pendukung terpenting dalam kepemimpinan yang dilakukan berdasarkan dan mengutamakan orientasi pada hubungan dengan anggota organisasi. Variabel gaya kepemimpinan ini secara operasional diukur dengan menggunakan tiga indikator yaitu

$$
\begin{array}{lr}
\text { gaya } & \text { kepemimpinan } \\
\text { transformasional, } & \text { transaksional } \\
\text { dan laissez-faire. } &
\end{array}
$$

2. Budaya Organisasi (X2) didefinisikan sebagai suatu kerangka kerja kognitif yang memuat sikap-sikap, nilai-nilai, norma-norma dan pengharapan pengharapan bersama yang dimiliki oleh anggota-anggota organisasi. Menurut Nongo (2012), budaya organisasi dapat diukur melalui indikator keterlibatan, konsistensi, adaptabilitas dan misi.

3. Kinerja karyawan (Y) adalah hasil kerja secara kualitas dan kuantitas yang di capai oleh seseorang karyawan dalam melaksanakan tugasnya sesuai dengan tanggung jawabyang di berikan kepadanya. Variabel kinerja ini secara operasional diukur dengan menggunakan empat indikator Stephen (2006) yaitu kuantitas, kualitas, efisensi dan kemampuan karyawan.

\section{Metode Analisis Data}

Metode analisis data yang digunakan dalam penelitian ini adalah analisis deskriptif dan analisis statistik dengan menggunakan teknik regresi linier berganda yang bertujuan untuk mencari bentuk hubungan (relasi) linier antara satu variabel terkait Y dan variabel bebas $\mathrm{X} 1, \mathrm{X} 2, \ldots$ Langkah selanjutnya setelah hasil regresi adalah uji ketepatan parameter penduga (uji t) dan uji ketepatan model (uji F dan $\mathrm{R}^{2}$ ).

\section{HASIL PENELITIAN DAN PEMBAHASAN \\ Hasil Penelitian \\ Untuk mengetahui pengaruh antara gaya kepemimpinan dan budaya}


organisasi terhadap kinerja karyawan pada PT. Japfa Comfeed Indonesia, Tbk Unit Makassar maka digunakan analisis regresi linier berganda, dimana variabel bebasnya adalah gaya kepemimpinan (X1) dan budaya organisasi (X2), serta variabel terikatnya adalah kinerja karyawan (Y). Berikut hasil uji regresi yang dilakukan.

Coefficients $^{\mathrm{a}}$

\begin{tabular}{|l|l|l|l|l|l|}
\hline \multirow{2}{*}{ Model } & \multicolumn{2}{|l|}{$\begin{array}{l}\text { Unstandardized } \\
\text { Coefficients }\end{array}$} & $\begin{array}{l}\text { Standardized } \\
\text { Coefficients }\end{array}$ & & \multirow{2}{*}{} \\
\cline { 2 - 5 } & $\mathrm{B}$ & Std. Error & Beta & $\mathrm{t}$ & Sig. \\
\hline $\begin{array}{l}\text { 1 } \quad \text { Constant) } \\
\quad \text { Gaya }\end{array}$ & 28,699 & 4,216 & & 6,808 &, 000 \\
$\quad$ Kepemimpinan &, 237 &, 064 &, 348 & 3,670 &, 000 \\
$\quad$ Budaya Organisasi &, 171 &, 076 &, 213 & 2,246 &, 027 \\
\hline
\end{tabular}

a. Dependent Variable: Kinerja Karyawan

Sumber: Data primer diolah, 2019

Dari hasil uji regresi berganda yang dilakukan pada tabel di atas, dapat dibuat persamaan sebagai berikut:

$\mathrm{Y}=28,699+0,237 \mathrm{X}_{1}+0,171 \mathrm{X}_{2}+\mathrm{e}$

Dari persamaan yang terbentuk di atas dapat dijelaskan interpretasinya sebagai berikut:

a $($ konstanta $)=28,699$ artinya apabila variabel gaya kepemimpinan (X1) dan budaya organisasi (X2) dalam keadaan konstan, maka akan mempengaruhi kinerja (Y) sebesar 28,699 satuan. b1 $=0,237$, artinya apabila variabel gaya kepemimpinan (X1) meningkat 1 satuan, maka kinerja karyawan (Y) akan meningkat sebesar 0,237satuan. b2 $=0,171, \quad$ artinya apabila variabel budaya organisasi (X2) meningkat 1 satuan, maka kinerja karyawan (Y) akan meningkat sebesar 0,171 satuan.

Untuk mengetahui keeratan hubungan antara variabel gaya kepemimpinan dan budaya organisasi dengan kinerja karyawan maka dilakukan uji korelasi. Dari hasil uji korelasi yang dilakukan didapat nilai korelasi (R) sebesar 0,431 yang signifikan pada $\alpha=0,05$. Hal ini menunjukkan bahwa ada hubungan yang sangat kuat dan signifikan antara variabel gaya kepemimpinan dan budaya organisasi dengan kinerja karyawan. Dapat dilihat tabel di bawah ini :

\section{Model Summary}

\begin{tabular}{|l|l|l|l|l|}
\hline Model & R & R Square & Adjusted R Square & $\begin{array}{l}\text { Std. Error of the } \\
\text { Estimate }\end{array}$ \\
\hline 1 &, $431^{\mathrm{a}}$ &, 786 &, 168 & 2,127 \\
\hline
\end{tabular}

a. Predictors: (Constant), Gaya Kepemimpinan, Budaya Organisasi

Sumber: Data primer diolah, 2019

Koefisien determinasi (R2) digunakan untuk mengetahui seberapa besar kontribusi variabel-variabel bebas dalam menjelaskan variasi variabel terikat. Dari tabel di atas diperoleh koefisien determinasi (R2) sebesar $0,786 \quad(78,6 \%)$. Ini berarti bahwa variasi variabel terikat kinerja karyawan (Y) dapat dijelaskan oleh variabel gaya kepemimpinan (X1) dan budaya organisasi (X2) sebesar 78,6\%, sedangkan sisanya 21,4\% dijelaskan oleh variabel-variabel lain diluar 
variabel yang diteliti.

Sedangkan Uji $\mathrm{t}$ dilakukan untuk mengetahui pengaruh variabel gaya kepemimpinan dan budaya organisasi terhadap kinerja karyawan secara parsial (sendiri-sendiri). Uji t dilakukan dengan membandingkan nilai $\mathrm{t}$ hitung dengan $\mathrm{t}$ tabel atau melihat nilai signifikansinya. Apabila t hitung > t tabel dan nilai signifikansi < $\alpha 0,05$, maka dikatakan pengaruhnya signifikan, dan apabila $\mathrm{t}$ hitung $<\mathrm{t}$ tabel dan nilai signifikansi $>\alpha 0,05$, maka dikatakan pengaruhnya tidak signifikan. Dari tabel di atas diperoleh $t$ hitung untuk variabel gaya kepemimpinan (X1) lebih besar dari $\mathrm{t}$ tabel, yakni 3,670>1,669 dan nilai signifikansi $0,000<\alpha \quad 0,05$. Jadi, variabel gaya kepemimpinanmempunyai pengaruh yang positif dan signifikan terhadap kinerja karyawan (Y) secara parsial. Thitung untuk variabel budaya organisasi (X2) lebih besar dari t tabel, yakni $2,246>1,66$ dan nilai signifikansi $0,027>\alpha 0,05$. Jadi, variabel budaya organisasi mempunyai pengaruh yang positif namun tidak signifikan terhadap kinerja karyawan (Y) secara parsial. Dari hasil uji t tersebut di atas dapat disimpulkan bahwa variabel yang paling dominan pengaruhnya terhadap kinerja karyawan pada PT. Japfa Comfeed Indonesia, Tbk Unit Makassar adalah variabel gaya kepemimpinan dengan nilai t hitung terbesar $(3,670)$ dan nilai signifikansi terkecil $(0,000)$.

Uji F dilakukan untuk mengetahui pengaruh variabel gaya kepemimpinan dan budaya organisasi terhadap kinerja karyawan secara simultan (bersama-sama). Uji F dilakukan dengan membandingkan nilai $\mathrm{F}$ hitung dengan $\mathrm{F}$ tabel. Apabila $\mathrm{F}$ hitung > F tabel, maka dikatakan pengaruhnya signifikan, dan apabila $\mathrm{F}$ hitung < F tabel, maka dikatakan pengaruhnya tidak signifikan. Berikut hasil uji F tabel :

ANOVA $^{\mathrm{a}}$

\begin{tabular}{|l|l|l|l|l|l|}
\hline Model & Sum of Squares & df & $\begin{array}{l}\text { Mean } \\
\text { Square }\end{array}$ & F & Sig. \\
\hline 1 Regression & 94,955 & 2 & 47,478 & 10,499 &, $000^{\text {b }}$ \\
Residual & 416,034 & 92 & 4,522 & & \\
Total & 510,989 & 94 & & & \\
\hline
\end{tabular}

a. Dependent Variable: Kinerja Karyawan

b. Predictors: (Constant), Gaya Kepemimpinan, Budaya Organisasi Sumber: Data primer diolah, 2019

Dari tabel di atas diperoleh $\mathrm{F}$ hitung lebih besar dari $\mathrm{F}$ tabel, yakni $10,499>3,09$. Jadi, variabel gaya kepemimpinan (X1) dan budaya organisasi (X2) mempunyai pengaruh yang positif dan signifikan terhadap kinerja karyawan (Y) secara simultan.

\section{Pembahasan \\ Pengaruh Gaya Kepemimpinan terhadap Kinerja Karyawan}

\begin{abstract}
Berdasarkan hasil penelitian menunjukan bahwa gaya kepemimpinan berpengaruh positif terhadap kinerja karyawan. Ogbonna dan Harris (2000) dalam penelitiannya menunjukkan bahwa kepemimpinan yang diperankan dengan baik oleh seorang pemimpin mampu memotivasi karyawan untuk bekerja lebih baik, hal ini akan membuat karyawan lebih hatihati berusaha mencapai target yang
\end{abstract}


diharapkan perusahaan, hal tersebut berdampak pada kinerjanya. Hasil penelitian ini sejalan dengan penelitian sebelumnya yang dilakukan oleh Suharyanto (2011) di Universitas PGRI Adi Buana Surabaya, Handoko (2012) di Pondok Serrata, Maulvinizar (2011) pada PT. Pos Indonesia (persero) cabang Kudus dan Arif (2010) pada PT. Bank mega cabang Semarang dimana kepemimpinan berpengaruh positif dan signifikan terhadap kinerja karyawan. Kepemimpinan berarti kemampuan untuk mempengaruhi, menggerakkan, dan mengarahkan suatu tindakan pada diri seseorang atau sekelompok orang untuk tujuan tertentu. Dalam upaya mempengaruhi tersebut seorang pemimpin menerapkan gaya yang berbeda-beda dalam setiap situasi. Kepemimpinan yang diperankan dengan baik oleh seorang pemimpin mampu memotivasi karyawan untuk bekerja lebih baik, hal ini akan membuat karyawan lebih hati-hati dalam berusaha mencapai target yang diharapkan perusahaan, hal tersebut berdampak pada kinerjanya.

\section{Pengaruh Budaya Organisasi terhadap Kinerja Karyawan}

Hasil penelitian Waridin dan Masrukhin (2006) menunjukan bahwa budaya organisasi yang diindikasikan dengan budaya dituntutnya pegawai mencari cara-cara yang lebih efektif dan berani menanggung resikonya, cermat dalam melaksanakan pekerjaan, perhatian pada kesejahteraan pegawai, tuntutan konsentrasi yang dicapai semangat yang tinggi dalam bekerja, serta kewajiban dalam merealisasikan target dan tugas instansi mempunyai pengaruh positif terhadap kinerja karyawan. Sheridan (1992), menunjukkan bahwa budaya organisasi secara signifikan berhubungan positif dengan kinerja karyawan, voluntary turnover dan komitmen organisasi. Dikatakan bahwa variasi dalam cultural value memiliki pengaruh terhadap tingkat turnover dan kinerja karyawan.

Hasil penelitian ini sejalan dengan penelitian sebelumnya yang dilakukan oleh Suharyanto (2011) di Universitas PGRI Adi Buana Surabaya, Teguh Rhiman Handoko (2012) di Pondok Serrata, Maulvinizar (2011) pada PT. Pos Indonesia (persero) cabang Kudus dan Rusdan Arif (2010) pada PT. Bank mega cabang Semarang dimana budaya organisasi berpengaruh positif dan signifikan terhadap kinerja karyawan. Budaya organisasi merupakan nilai keyakinan bersama yang mendasari identitas perusahaan dan suatu kesepakatan bersama para anggota dalam organisasi atau perusahaan sehingga mempermudah lahirnya kesepakatan yang lebih luas untuk kepentingan perorangan. Budaya organisasi menjadi pengendali dan arah dalam membentuk sikap dan perilaku manusia yang melibatkan diri dalam suatu kegiatan organisasi. Budaya organisasi mempengaruhi produktivitas, kinerja, komitmen, kepercayaan diri, dan perilaku etis.

\section{KESIMPULAN}

Berdasarkan hasil analisis data yang diperoleh menggunkan analisis regresi berganda. Analisis ini mencakup analisis regresi berganda, pengujian hipotesis melalui uji $\mathrm{t}$, dan $\mathrm{f}$, serta analisis koefisien determinasi (R2). Dari analisis tersebut diperoleh analisis regresi : $\mathrm{Y}=28,699+0,237 \mathrm{X}_{1}$ $+0,171 \mathrm{X}_{2}+\mathrm{e}$, maka dapat disimpulkan sebagai berikut:

1. $\mathrm{a}=28,699$. Dari hasil tersebut menunjukkan Gaya kepemimpinan dan Budaya organisasi mempunyai 
pengaruh positif terhadap kinerja karyawan.

2. $\mathrm{b}_{1}=0,237$. Dari hasil tersebut menunjukkan pengaruh positif yaitu apabila Gaya Kepemimpinan yang diberikan semakin meningkat maka mengakibatkan kinerja karyawan meningkat.

3. $b_{2}=0,171$. Dari hasil tersebut menunjukkan pengaruh positif yaitu apabila budaya organisasi yang diberikan semakin meningkat, maka mengakibatkan kinerja karyawan meningkat.

\section{Saran}

Berdasarkan analisis dan kesimpulan, maka dapat disampaikan saran-saran sebagai berikut:

1. Hasil analisis data menunjukkan adanya pengaruh positif antara gaya kepemimpinan dan budaya organisasi terhadap kinerja karyawan, maka perlu diperhatikan atau perlu ditingkatkan lagi terutama indikator yang ada dalam budaya organisasi.

2. Perlu melakukan upaya peningkatan kinerja karyawan dengan prinsip pendekatan yang terkait dengan budaya organissi melalui indikator keterlibatan, konsistensi, adaptabilitas dan misi.

3. Dalam usaha meningkatkan kinerja karyawan karyawan, maka seyogyanya PT. Japfa Comfeed Indonesia, Tbk Unit Makassar memperhatikan budaya organisasi berupa pemberian tambahan pendapatan kepada karyawan yang berprestasi, memberikan peningkatan tunjangan kesejahteraan dan kesehatan yang memadai.

\section{DAFTAR PUSTAKA}

Alghazo, A. M. \& Al-Anazi, M., 2016.
The Impact of Leadership Style on Employee's Motivation. International Journal of Economics and Business Administration, 2(5), pp. 37-44 Avolio, B.J., Waldman, D.A. \& Yammarino, F.J. (1991). Leading in the 1990s: The four $i^{\text {ee }} \mathrm{s}$ of transformational leadership. Journal of European industrial training,15(4)

Baron, Jame. M. dan Kreps, David. M. (1999). Strategy Human Resources Framework for General Manager. John Wiley \& sons. Inc. New York

Bernardin, John $\mathrm{H}$ dan Joyce A. Russel. (1998). Human Resource Management: An Experiental Approach. New Jersey: McGraw-Hill

Byars, Lloyd. L 1984, Manajemen Sumberdaya Manusia, Andi Offset, Yogyakarta

Bycio, P., Hackett, R.D. and Allen, J.S. (1995) 'Further Assessments of Bass's (1985) Conceptualization of Transactional and Transformational Leadership', Journal of Applied Psychology , 80(4): 468-78

Colquitt, J., LePine J., \& Wesson M. 2009. Organizational Behavior: Improving Performance and Commitment in the Workplace. New York: McGraw-Hill

Dessler, Garry, 1992, "Manajemen Sumber Daya Manusia”, PT Prenhalindo, Jakarta

Denison, D.R. (1990) Corporate Culture and Organisational Effectiveness. New York: Wiley

Elkins, T., \& Keller, R.T. (2003) Leadership in research and development organizations: a literature review and conceptual framework. The 
Leadership Quarterly. 14, 587596.

Forehand, G. A. and Von Gilmer, (1964). Environmental Variations in Studies of Organizational Behavior. Psychological Bulletin, 62, 361-382.

Gibson, Ivancevich, Bonnelly. 1996. Organisasi Perilaku Struktur Proses. Jillid I. Jakarta: Bina Rupa Aksara.

Gopal, R. and R. G. Chowdhury: 2014, 'Leadership Styles And Employee Motivation: An Empirical Investigation In A Leading Oil Company In India'. International Journal of Research in Business Management 2(5).

Hasibuan, Malayu. 2002. Manajemen Sumber Daya Manusia. Bandung : Refika Aditama

Hartog, D.N.D. and P.L. Koopman (2011) Leadership in Organizations. Handbook of Industrial, Work \& Organizational Psychology Vol.2.166-187 SAGE Publications

Howell, J.M. and Avolio, B.J. (1993) 'Transformational Leadership, Transactional Leadership, Locus of Control and Support for Innovation: Key Predictors of Consolidated-Business-Unit Performance', Journal of Applied Psychology, 78: 891902

Huang X., I. Joyce, A. Liu, Y. Gong, (2010), "Does participative leadership enhance work performance by inducing empowerment or trust? The differential Effects on Managerial and Nonmanagerial Subordinates", J. of Organizational Behavior, 31, 122-143
Hurduzue, R.-E., 2015. The Impact Of Leadership On Organizational Performance. Sea-Practical Application of Science, 3(1(7)), pp. 289-294.

Kark, Ronit, Waismel-Manor, Ronit, Shamir, Boas, (2012), Does valuing androgyny and femininity lead to a female advantage? The relationship between gender-role, transformational leadership and identification", The Leadership Quarterly, Vol. 23, pp 620-640.

Lewin, A Y and Minton, J W (1986)

Determining Organizational Effectiveness: Another Look, and An Agenda for Research. "Management Science", 32(5), 514-538

Low, S P and Shi, Y (2001) Cultural Influences on organizational Processes in International Projects: Two Case Studies. "International Journal of Productivity and Performance Management", 50(6), 267-85.

Mangkunegara Anwar Prabu. 2000. Manajemen Sumber Daya Manusia. Cetakan Pertama. Rosda. Bandung

Mintzberg, H. (2010). Developing Leaders? Developing Countries? Oxford Leadership journal , 1 (2)

Mullins .L. J, (2005), "Management and organizational behavior" in Dolatabadi, R. H., and Safa, M., (2010), "The Effect of Directive and Participative Leadership Style on Employees' Commitment to Service Quality", Euro Journals - International Bulletin of Business Administration

Neely,A.D., Mike Gregory and Ken Platts (1995) "Performance measurement system design A literature review and research 
agenda", International Journal of Operations \& Production Management Vol. 25 No. 12, 2005 pp. 1228- 1263 IJOPM Volume 15 Issue 4, pp. 80-116

Nongo, D. S. (2012). The Impact Of Organisational Culture On Corporate Effectiveness Of The Cement Manufacturing Industry In Nigeria. International Journal of Business and Management Tomorrow, 2(2), 1-9.

Nongo, E. S. \& Ikyanyon1, D. N. (2012).The Influence of Corporate Culture on Employee Commitment to the Organization. International Journal of Business and Management, 7(22), 21-28.

Northouse, P.G. (2012). Leadership: Theory and practice. Sage Publications

Robbins, Stephen P, 2003. Organizatonal Behaviour. Teth Edition, Pearson Education, Inc New Jersey.

Rue, L. \& Byars, L. (2009). Management: Skills and Application. McGraw-Hill Education, ISBN 9780073381503.

Rue, LW, LL Byars, (1980). Management: Theory and Application, New York: Ricard D. Irwin Inc, Homewood IL

Russell, R.V. (2005). Leadership in recreation. New York: McGraw-Hill., 3rd edition

Saffold, G. S. (2011). Culture traits, strength, and organizational performance: Moving beyond "strong" culture. Academy of Management Review, 13, 546558.

Smart, J C and John, E P S (1996) Organizational Culture and Effectiveness in Higher Education: A
Test of the Culture Type and Strong Culture Hypotheses. "Educational Evaluation and Policy Analysis", 18(3), 219241

Smircich, L. (2010). Concepts of culture and organizational analysis. Administrative Science Quarterly, 28, 339-358.

Stone, A.G., Russell, R.F. \& Patterson, K. (2004). Transformational versus servant leadership: A difference in leader focus. Leadership \& Organization Development Journal, 25(4), pp. 349-361.

Soeprihanto, John. 2000. Penelitian Kinerja dan Pengembangan Karyawan. Edisi Pertama. BPFE, Yogyakarta.

Suharyanto (2011).' pengaruh gaya kepemimpinan dan budaya organisasi terhadap kinerja pegawai di Universitas PGRI Adi Buana Surabaya

Trice, H. M.; Beyer, J. M. (1991), Cultural Leadership in Organizations, Organization Science, Vol. 2 Issue 2, p149169.

Tsui S., Zhang, Z., Wang, H., Xin, K. R., and $\mathrm{Wu}, \quad J$. B. (2010).Unpacking the relationship between CEO leadership behavior and organizational culture, The Leadership Quarterly, 17, 113137

Yuan. K, CH.Lee. Y, CH.(2011). Exploration of a construct model linking leadership types, organization culture, employees performance and leadership performance. Procedia - Social and Behavioral Sciences. Vol. 25, pp. $123 \quad-\quad 13$ 
ISSN 2656-2790 (online) 